\title{
Effects of Sex Steroids on Fish Leukocytes
}

\author{
Elena Chaves-Pozo ${ }^{1}$ (i), Alfonsa García-Ayala ${ }^{2, *}$ (i) and Isabel Cabas ${ }^{2}$ \\ 1 Centro Oceanográfico de Murcia, Instituto Español de Oceanografía, 30860 Puerto de Mazarrón, Spain; \\ elena.chaves@ieo.es \\ 2 Department of Cell Biology and Histology, Regional Campus of International Excellence "Campus Mare \\ Nostrum," University of Murcia, 30100 Murcia, Spain; icabas@um.es \\ * Correspondence: agayala@um.es; Tel.: +34-868-884968; Fax: +34-868-883963
}

Received: 11 November 2017; Accepted: 4 January 2018; Published: 9 January 2018

\begin{abstract}
In vertebrates, in addition to their classically reproductive functions, steroids regulate the immune system. This action is possible mainly due to the presence of steroid receptors in the different immune cell types. Much evidence suggests that the immune system of fish is vulnerable to xenosteroids, which are ubiquitous in the aquatic environment. In vivo and in vitro assays have amply demonstrated that oestrogens interfere with both the innate and the adaptive immune system of fish by regulating the main leukocyte activities and transcriptional genes. They activate nuclear oestrogen receptors and/or G-protein coupled oestrogen receptor. Less understood is the role of androgens in the immune system, mainly due to the complexity of the transcriptional regulation of androgen receptors in fish. The aim of this manuscript is to review our present knowledge concerning the effect of sex steroid hormones and the presence of their receptors on fish leukocytes, taking into consideration that the studies performed vary as regard the fish species, doses, exposure protocols and hormones used. Moreover, we also include evidence of the probable role of progestins in the regulation of the immune system of fish.
\end{abstract}

Keywords: oestrogens; androgens; progestins; immune system; leukocytes; teleosts

\section{Introduction}

Steroids regulate several biological processes, including embryonic development, sex differentiation, reproduction, metabolism, circadian rhythms and immune and stress response in vertebrates [1]. Regarding the immune response, it has been known for many years that steroids act on all immune cell types through steroid receptor-dependent and receptor-independent mechanisms [2]. Recently, the presence of a great variety of substances, both natural and anthropogenic, in aquatic media has aroused interest in determining the effect of steroids on different aspects of fish biology, including the immune response. These structurally diverse substances have been shown to disrupt the function (blocking- or super-activating hormone receptors), the levels (interfering with hormone biosynthesis and metabolism) or the distribution of endogenous hormones and are, as such, classified as endocrine disrupting chemicals (EDCs) [3,4]. The EDCs, which interfere with hormone biosynthesis and metabolism, act either as inhibitors of relevant steroidogenic enzymes, or at expression levels [5]. In the International Program on Chemical Safety (IPCS) 2012, EDCs were defined as "an exogenous substance or mixture that alters function(s) of the endocrine system and consequently causes adverse health effects in an intact organism, or its progeny, or (sub) populations"; those substances disrupting the steroid regulation can be designated as xenosteroids, with further subclasses of xenoestrogens or xenoandrogens [6].

Steroidogenesis occurs primarily in different peripheral tissues like the gonads, the interrenal gland and the brain [1,7], which produce both oestrogens (C18 steroids) and androgens (C19 steroids). A schematic representation of the key steps involved in steroidogenesis in teleosts is shown in 
Figure 1. All classes of steroid hormones are synthesized de novo from the common precursor cholesterol [8], which is imported by the steroidogenic acute regulatory protein (StAR) into the inner mitochondrial membrane in a rate-limiting reaction [9]. Downstream of the synthesis pathway, several enzymes modify the steroid nucleus and add and modify functional groups through hydroxylation, reduction, or oxidation reviewed by [1]. Although $17 \beta$-estradiol $\left(\mathrm{E}_{2}\right)$ is the major oestrogen in females, it is also important for normal male reproduction [10]. In fish, detectable levels of $E_{2}$ have been reported during the reproductive cycle of male specimens of several fish species [10-12]. As regards androgens, dihydrotestosterone (DHT) is one of the most physiologically important androgens in many male vertebrates; in fish, it has recently been demonstrated that DHT plays a role in early development and reproduction [13]. Moreover, in fish, testosterone (T), 11-ketotestosterone (11KT) and $11 \beta$-hydroxytestosterone (OHT) are found in serum or testes of several species [14]. The third group of sex steroid hormones consists on progestins, which have traditionally been related with the final events of maturation of fish gametes $[15,16]$; however, it has also been demonstrated their role in the early stages of spermatogenesis [17]. Sex steroid production and modification, as well as serum steroid levels, are regulated by different parameters such as substrate availability, rapid changes in steroidogenic enzyme activity, the regulation of transcription levels of these enzymes and the amount of sex steroids binding proteins in blood and tissues [14,18]. All the biological processes including immunity are under the influence of seasonal changes such as photoperiod and temperature and reproductive conditions $[19,20]$. Interestingly, the seasonality associated with immunity has been related to several hormone such as melatonin, cortisol and sex steroids $[19,21]$. Most of the data revealed that seasonal changes in sex steroid hormones modulate several immune activities in serum and immune tissues but also revealed that peripheral immune activities such as the gonadal immune responses depends on the reproductive conditions of the specimens $[12,22]$.

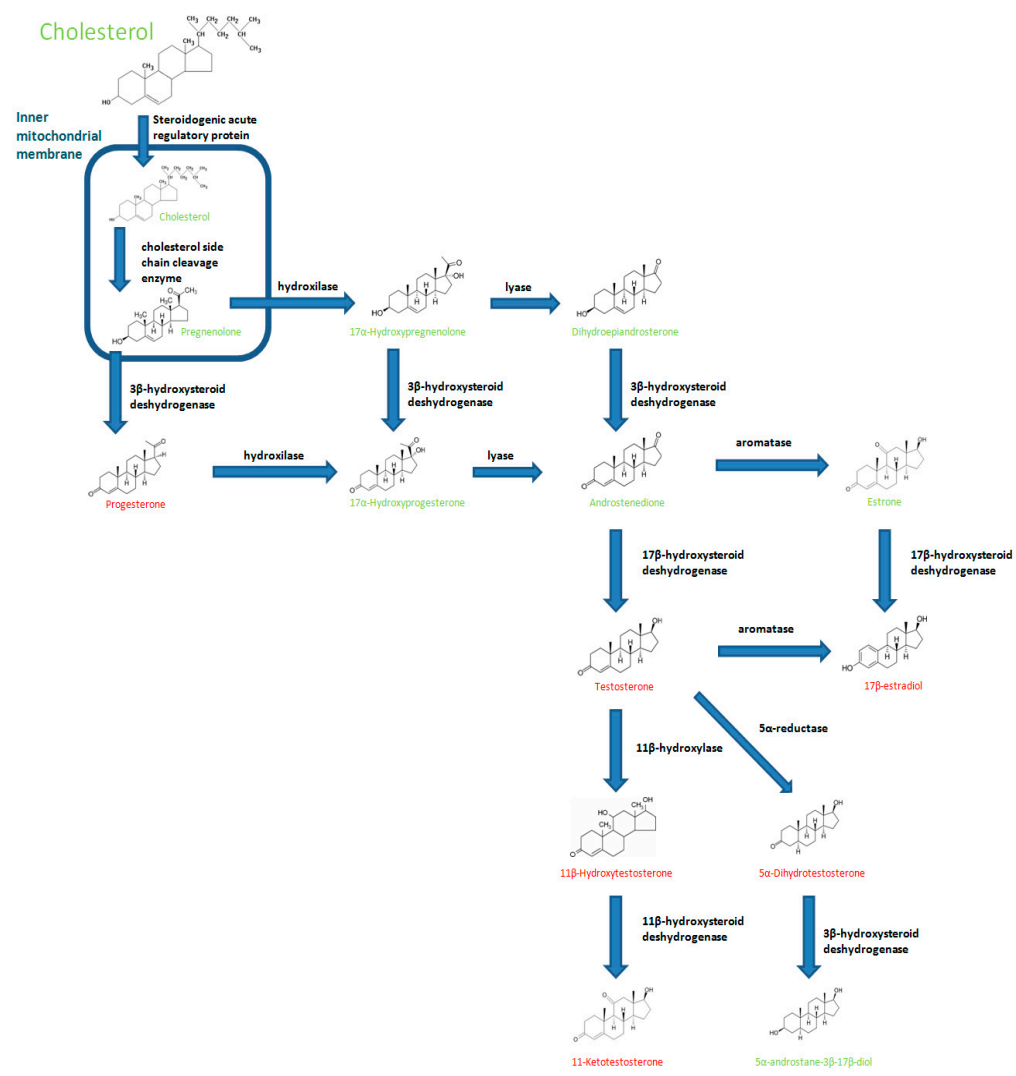

Figure 1. Schematic representation of the key steps involved in fish sex steroids (written in red) production (modified from [23]). 
The presence of specific sex steroid receptors on fish immune cells implies direct steroid-mediated immune regulation [24]. Two different types of sex steroids receptors have been described: (i) the classical nuclear receptors, which act as transcriptional regulators of genes containing oestrogen response elements in their promoter regions [25] and (ii) the membrane receptors, which are G protein-coupled receptors that mediate a rapid signalling effect of sex steroids [26]. A schematic representation of the presence of oestrogen and androgen receptors on fish leukocytes accordingly to functional and gene expression data obtained in gilthead seabream is shown in Figure 2.

As regards the immune system, teleost fish was the first evolutionary group to possess both innate and adaptive immunity response [27]. The innate immune system is considered essential for fish as they are aquatic free-living organisms from the early embryonic stages of life, poikilothermics and with a limited immunoglobulin repertoire $[27,28]$. Some studies have pointed out that the immune response of both wild and farmed fish can be influenced by a variety of parameters, among which temperature, stress management, fish density, light, water quality, salinity, food or immunostimulants should be mentioned [29-34].

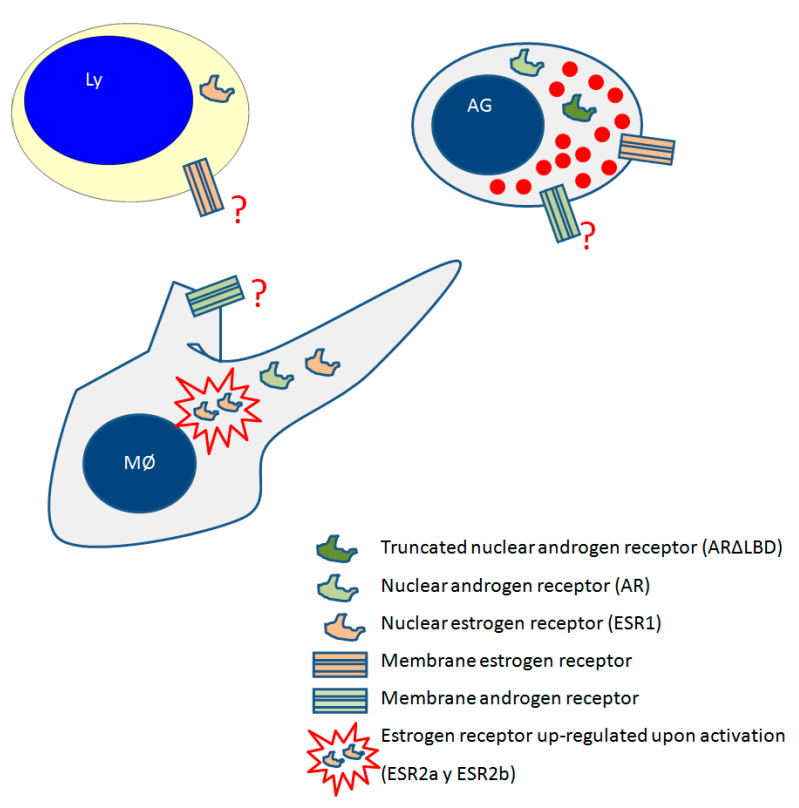

Figure 2. Schematic representation of the presence of oestrogen and androgen receptors in fish leukocytes accordingly to functional and gene expression data obtained in gilthead seabream. Ly, lymphocyte; AG, acidophilic granulocyte; $\mathrm{M} \varnothing$, macrophage; probable receptor location accordingly to functional data but not demonstrated to date.

In innate immunity, the epithelium and mucosal tissues represent the physical barriers, while phagocytes (granulocytes and monocytes/macrophages), non-specific cytotoxic cells and eosinophilic cells, including mast cells, represent the cellular effectors; meanwhile, a variety of molecules (the complement, acute phase proteins, antimicrobial polypeptides, natural antibodies and cytokines, between others) direct the humoral immune response. The main mechanisms of the innate immunity developed in teleost fish to destroy harmful stimuli include activities such as degranulation, chemotaxis, phagocytosis, production of reactive oxygen intermediates (ROIs) and nitric intermediate production and opsonic and haemolytic serum activities [35]. The innate immune mechanisms are specific for common structures in microbial groups but are unable to distinguish between small differences in exogenous pattern recognition receptors (PRRs), which include Toll-like receptors (TLRs), retinoic acid-inducible gene I-like receptors, nucleotide-binding oligomerization domain-like receptors and C-type lectin receptors [36]. These receptors recognize the pathogen-associated molecular patterns conserved in pathogenic organisms such as polysaccharides, lipopolysaccharides (LPS), bacterial 
DNA or viral RNA. These PRRs also recognize endogenous molecules released from damaged cells, known as damage-associated molecular patterns [36].

The adaptive immune response includes lymphocytes (B and T cells) as cellular components and secreted antibodies (immunoglobulins, Ig) as the humoral component [35].

Fish B cells are mainly produced in the head kidney, followed by the thymus and spleen [37-40]. Teleost B cells produce Ig to specifically label altered-host or foreign cells in order to agglutinate or precipitate soluble antigens, promoting phagocytosis [41]. In cartilaginous fish, three heavy chain isotypes have been detected: IgM, IgW, which has been referenced with many names (IgX, IgNARC or $\operatorname{IgR}$ ) before it was proposed as an orthologue of $\operatorname{IgD}$, and the lineage-specific isotype IgNAR [42-46]. Regarding teleost fish, three different Ig have been identified to date: $\operatorname{IgM}$ [47], $\operatorname{IgD}$ [48] and IgT/Z [49]. A tetramer of the IgM class containing eight antigenic combining sites is the most predominant Ig in teleost fish [47]. Based on the discovery of these three Ig in fish and their expression on B cells, several B cell subsets have been identified in different fish species pointing to a great diversity between them $[39,50,51]$. Moreover, the alternative splicing of pre-mRNA performed in fish (for review see $[52,53])$ suggests that the specific immune response of teleost fish might be as complex as in mammalian. Although there is no evidence concerning the presence of IgE, IgA or IgG in teleost fish, a functional FceRI receptor has been described [54], which, in mammals, acts as an IgE receptor. In mammals, $\mathrm{T}$ cells are categorized into two general populations: $\mathrm{T}$ cytotoxic $(\mathrm{Tc})$ and $\mathrm{T}$ helper (Th) cells. The existence of Tc cells in fish, where they would be involved in specific cell-mediated cytotoxicity, has been suggested [55]. In fish, many molecules representing different Th cell subsets and their transcription factors have been demonstrated both at genetic and functional level [56,57]; however, further characterization of fish Th responses and the polarization of Th cells into Th subsets is needed [58,59]. As in mammals, the adaptive immune response of teleost $\mathrm{T}$ cells is thought to be mediated by the production of cytokines $[41,60]$.

The aim of this manuscript is to review our present knowledge concerning the effect of sex steroids on fish leukocytes, taking into consideration that the studies performed vary as regards the fish species, doses, exposure protocols and hormones used.

\section{Influence of Oestrogens on Fish Immune Responses}

Oestrogens are involved in the regulation of oogenesis, vitellogenesis, testicular development and some other aspects of reproduction; in addition, they play important regulatory roles in many other systems (for review [61]). The immunomodulatory actions of oestrogens have been well documented for the mammalian immune system. In fish, this information is more limited although it has been known for many years that oestrogens regulate the immune system of fish [62-66] and several leukocyte functions [63,67-71]. Numerous studies have produced a substantial body of data concerning the effect of $E_{2}$ on the fish immune response based on experimental in vivo and in vitro assays in which the activities of different immune cell types at different stages of their reproductive cycles were analysed (Table 1). The results permit to conclude that $E_{2}$ influence the immune response of fish.

The effect of $E_{2}$ on the immune response of gilthead seabream, a hermaphrodite fish species, has been widely studied, focusing on their leukocyte activities. In this species, the main phagocytic cell type, the acidophilic granulocytes, is strongly influenced by serum $E_{2}$ levels although they do not express nuclear oestrogen receptors (ESRs). An increase in serum $\mathrm{E}_{2}$ levels promotes the movement of this cell type from the head kidney (the major haematopoietic organ in fish), as occurred after an inflammation response [72]. $E_{2}$ also increases the transcription of some leukocyte adhesion molecules in vascular endothelial cells [65], promoting the recruitment of acidophilic granulocytes. Moreover, $\mathrm{E}_{2}$ enhance inflammation by increasing the production of a pro-inflammatory cytokine, the interleukin-1 $\beta$ (IL1 $\beta$ ), in head kidney phagocytes [67]. In contrast to these data, head kidney macrophages of goldfish (Carassius auratus), previously treated with $\mathrm{E}_{2}$, show a decrease in their chemotactic response against endotoxin activated goldfish serum [69]. In gilthead seabream, $E_{2}$ also has an inhibitory effect on acidophilic granulocytes as it inhibits their ROIs production activity [67]. 
Gilthead seabream macrophages also respond to $E_{2}$, which alters the expression pattern of genes related with immunity [63]. As occurs in gilthead seabream, the in vivo $E_{2}$ treatment inhibits the production of ROIs in rainbow trout (Oncorhynchus mykiss) and common carp (Cyprinus carpio) phagocytes [70,73] and nitric oxide (NO) production and phagocytic capability in common carp phagocytes [70]. However, the in vitro exposure of common carp and goldfish head kidney macrophages to $E_{2}$ has no effect on ROI and NO production and slightly decreases their phagocytic capability $[69,71]$. This difference between the in vivo and in vitro effects in the same species might be explained by the data obtained for gilthead seabream that point to interactions between different immune cell types upon $E_{2}$ treatment. Thus, macrophage conditioned media, obtained from $\mathrm{E}_{2}$ treated-macrophages, modify the phagocytic capability and ROIs production activity of head kidney cells in a similar way as $E_{2}$ treatment [66]. Interestingly, the effect of $\mathrm{E}_{2}$ might be species-specific, as the effect is not the same in other fish species. For example, in Japanese sea bass (Lateolabrax japonicus), $\mathrm{E}_{2}$ increases the production of ROIs by blood macrophages and liver cells [74,75]. As regards pro-inflammatory cytokines, exposure of European sea bass juveniles to $E_{2}$ for 35 days decreased the il1 $\beta$ and tumour necrosis factor $\alpha(\operatorname{tnf} \alpha)$ transcriptional levels and the IL1 $\beta$ content in serum. However, these effects were not constant with time [76].

Interestingly, chronic exposure to $\mathrm{E}_{2}$ during embryonic development, hatching and early larval development of rainbow trout fry leads to an impairment of the complement activation pathway upon a bacterial challenge and a concomitant decrease in the survival rate of the population exposed to $E_{2}$ compared to non-exposed groups [77].

When the adaptive immune response is studied, species-dependent effects were also observed. Regarding total levels of IgM, they fell upon $\mathrm{E}_{2}$ treatment in gilthead seabream and rainbow trout (Oncorhynchus mykiss) but increased in Japanese sea bass [75,78-80]. Interestingly, in rainbow trout the amount of IgM-secreting cells was suppressed by $\mathrm{E}_{2}$ but were not affected in common carp [73,81]. Moreover, $E_{2}$ impaired the mitogen-proliferation of peripheral blood leukocytes of goldfish in vivo and suppressed this activity in vitro in goldfish and catfish peripheral blood leukocytes $[82,83]$.

Briefly, as it is not the main subject of this revision, $17 \alpha$-ethynylestradiol $\left(\mathrm{EE}_{2}\right)$, a pharmacological compound with strong estrogenic activity used in oral contraceptives and in hormone replacement therapy, is widely distributed in superficial waters, where it acts as an EDC in fish. The presence of $\mathrm{EE}_{2}$ in the European sewage and surface waters (ranging from 0.5 to $62 \mathrm{ng} / \mathrm{L}[84,85]$ ) and the evidence of its effects in aquatic organisms, even at very low doses [86], have prompted to the European Union to include this substance in the monitoring programs of water pollution (document COM(2011)876; http:/ / eur-lex.europa.eu/legal-content/EN/TXT/?uri=COM:2011:0876:FIN). Several in vivo and in vitro assays have amply demonstrated that $\mathrm{EE}_{2}$ might alter the capacity of fish to appropriately respond to infection although it does not behave as an immunosuppressor in juveniles or adult gilthead seabream $[64,87,88]$. In fact, $\mathrm{EE}_{2}$ triggered an inflammatory response in the peritoneal exudates of gilthead seabream [89]. Interestingly, the innate immune response of fish recover from the disruptive effects of $\mathrm{EE}_{2}[87,88]$. 
Table 1. Effects of $17 \beta$-estradiol $\left(\mathrm{E}_{2}\right)$, testosterone $(\mathrm{T})$ or 11-ketotestosterone $(11 \mathrm{KT})$ on different types of leukocytes using in vivo and in vitro experiments in different teleost species.

\begin{tabular}{|c|c|c|c|c|c|}
\hline Sex Steroids & Leukocytes & Treatment & Effects & Fish Species & References \\
\hline \multirow{21}{*}{$E_{2}$} & \multirow{3}{*}{ Head kidney cells } & In vivo & Decrease of IL1 $\beta$ and TNF $\alpha$ transcription and IL1 $\beta$ production & European sea bass & {$[76]$} \\
\hline & & In vitro & Increase of IL $1 \beta$ production & Gilthead seabream & [67] \\
\hline & & In vitro & Inhibition of ROIs production activity & Gilthead seabream & [67] \\
\hline & $\begin{array}{l}\text { Head kidney } \\
\text { acidophilic granulocytes }\end{array}$ & In vivo & Migration from head kidney to peripheral tissues & Gilthead seabream & [72] \\
\hline & Macrophages & In vivo & Inhibition of ROIs production activity & Rainbow trout & [73] \\
\hline & Blood macrophages & In vivo & Increases of ROIs production activity & Japanese sea bass & [75] \\
\hline & \multirow{2}{*}{ Phagocytes } & In vivo & Inhibition of NO production & Common carp & [70] \\
\hline & & In vivo & Inhibition of ROIs production activity & Common carp & [70] \\
\hline & \multirow{6}{*}{$\begin{array}{c}\text { Head } \\
\text { kidney macrophages }\end{array}$} & In vitro & Inhibition of chemotaxis against endotoxin & Goldfish & [69] \\
\hline & & In vitro & Impartment of the immune-related gene expression pattern & Gilthead seabream & [63] \\
\hline & & In vitro & Non-effect on ROIs and NO production & Common carp & [71] \\
\hline & & In vitro & Non-effect on ROIs and NO production & Goldfish & [69] \\
\hline & & In vitro & Inhibition of the phagocytic capability & Common carp & [71] \\
\hline & & In vitro & Inhibition of the phagocytic capability & Goldfish & [69] \\
\hline & \multirow{3}{*}{$\begin{array}{c}\text { Peripheral } \\
\text { blood leukocytes }\end{array}$} & In vitro & Suppression of mitogenic activity & Goldfish & [83] \\
\hline & & In vitro & Suppression of mitogenic activity & Channel catfish & [82] \\
\hline & & In vivo & Impairment of mitogenic activity & Goldfish & [83] \\
\hline & \multirow{4}{*}{ IgM-secreting cells } & In vivo & Impairment of mitogenic activity & Goldfish & [83] \\
\hline & & In vivo & Decreases on IgM production & Gilthead seabream & [78] \\
\hline & & In vivo & Decreases on IgM production & Rainbow trout & [73] \\
\hline & & In vivo & Increases on IgM production & Japanese sea bass & [75] \\
\hline & \multirow{5}{*}{ Head kidney leukocytes } & In vivo & Increases of IL1 $\beta$ and TLRs transcription & Gilthead seabream & [90] \\
\hline & & In vitro and & Increases on ROIs production & Gilthead seabream & {$[90,91]$} \\
\hline & & In vitro & Non-effect on ROIs production & Tilapia & [68] \\
\hline & & In vitro & Increases on phasocytosis & Common carp & [68] \\
\hline & & In vitro & Increases on phagocytosis & Gilthead seabream & [91] \\
\hline & Acidophilic granulocytes & In vitro & Increases of IL $1 \beta$ and TLRs transcription & Gilthead seabream & [91] \\
\hline & \multirow{2}{*}{ Blood leukocytes } & In vivo & Non-effect on lysozyme activity & Tench & [92] \\
\hline & & In vivo & Non-effect on ROIs production & Tench & [92] \\
\hline & \multirow{3}{*}{ IgM-secreting cells } & In vitro & Decreases in number in blood, head-kidney, spleen and skin & Chinook salmon & [93] \\
\hline & & In vitro & Reduction in spleen & Rainbow trout & [80] \\
\hline & & In vitro & $\begin{array}{l}\text { Non-effect in head-kidney } \\
\text { Non-effect in blood }\end{array}$ & Common carp & [81] \\
\hline
\end{tabular}


Table 1. Cont.

\begin{tabular}{|c|c|c|c|c|c|}
\hline Sex Steroids & Leukocytes & Treatment & Effects & Fish Species & References \\
\hline \multirow{11}{*}{$11 \mathrm{KT}$} & \multirow{3}{*}{$\begin{array}{l}\text { Head-kidney } \\
\text { macrophages }\end{array}$} & In vivo & Inhibition of ROIs production & Common carp & [70] \\
\hline & & In vivo & Inhibition of phagocytosis & Common carp & [70] \\
\hline & & In vitro & Increases of TLRs and IL1 $\beta$ transcription & Gilthead seabream & [91] \\
\hline & \multirow{2}{*}{ Blood leukocytes } & In vitro & \multirow{2}{*}{ Non-effect on phagocytosis } & Common carp & [68] \\
\hline & & In vitro & & Tilapia & [68] \\
\hline & \multirow{3}{*}{ Head kidney phagocytes } & In vitro & Activation of ROIs production & Gilthead seabream & [67] \\
\hline & & In vitro & Increases pro-IL1 $\beta$ accumulation & Gilthead seabream & [67] \\
\hline & & In vivo & Inhibition of ROIs production & Three-spine sticklebacks & [94] \\
\hline & $\begin{array}{l}\text { Head kidney acidophilic } \\
\text { granulocytes }\end{array}$ & In vitro & Decreases of TLRs transcription & Gilthead seabream & [91] \\
\hline & \multirow{2}{*}{ IgM-secreting cells } & $\begin{array}{l}\text { In vivo and } \\
\text { in vitro }\end{array}$ & Decreases production & Rainbow trout & {$[79,80]$} \\
\hline & & In vitro & Decreases in number in blood, head-kidney, spleen and skin & Rainbow trout & [80] \\
\hline
\end{tabular}




\section{Oestrogen Receptor in Fish Leukocytes}

Three nuclear ESRs (ESR1, ESR2a and ESR2b) have been cloned in most fish species studied (including gilthead seabream, Atlantic croaker, zebrafish, goldfish and European eel), while four ESRs (two ESR1 and two ESR2b) have been described in rainbow trout and Spinibarbus denticulatus [62,95]. A tissue-specific pattern of expression in fish immune tissues has been observed for nuclear ESRs (Table 2). In channel catfish, ESR1 is expressed in spleen, blood and head kidney, while ESR2 is only expressed in spleen [96]. ESR2 is expressed in the spleen and head kidney of common sole (Solea solea) [97]. In gilthead seabream, macrophages, lymphocytes and total peritoneal leukocytes express ESR1 while acidophilic granulocytes, as already mentioned, did not express any ESRs [66,89]. In European sea bass all ESRs have been identify in thymocytes at transcriptional levels and in thymocytes and mast cells at protein levels [98]. Interestingly, common carp head kidney monocytes/macrophages, neutrophils and lymphocytes expressed ESR1 and ESR2 but they were not found in naïve blood circulating leukocytes [99], suggesting that the effect of $E_{2}$ on several immune cells also depend on the activation stage of leukocytes. The impairment of the ESR2b in a zebrafish mutant enhanced the susceptibility to anti-viral infections, although several genes related to the interferon pathway, including a negative regulator, were up-regulated in mutant fish [100]. However, these data do not explain the high loss in resistance upon viral infection recorded in mutant and compared with wild type fish, suggesting that anti-viral responses other than the interferon pathway might be affected by $\mathrm{E}_{2}$ signalling impairment.

It has been recognized for over 40 years that oestrogens, in addition to their classic genomic actions, can modulate several different signalling cascades in a non-genomic way [101]. Therefore, other receptors must also be involved because $\mathrm{E}_{2}$ actions have been described in cells lacking ESRs [102-104]. Despite the rapid effects of oestrogens had been identified earlier, it was not until 2005, that an orphan G-protein coupled receptor (GPCR) was identified as an oestrogen-binding intracellular membrane receptor [105-107].

In fish, European eel show two G-protein coupled oestrogen receptors (GPER: GPERa and GPERb) in reproductive tissues [108]. Although two GPERs are expected in most fish species as a consequence of genome duplication events that have occurred in fish, only one GPER has been characterized in most of the species studied, such as goldfish, gilthead seabream, Atlantic croaker, zebrafish, common carp and orange-spotted grouper (Epinephelus coioides) [7,99,109-112]. In gilthead seabream, GPER is expressed in acidophilic granulocytes but also in other leukocytes such as spleen and peritoneal leukocytes $[89,109]$, although the correct identification of these leukocytes needs further studies. In acidophilic granulocytes, G1 (a specific agonist of GPER) promotes, in a very short time (less than $16 \mathrm{~h}$ ), an anti-inflammatory effect both in vitro and in vivo mainly in naïve cells and non-vaccinated fish. Interestingly, GPER hardly modifies the ROIs production of acidophilic granulocytes [109]. In addition, GPER signalling in vivo modulated the adaptive immunity in gilthead seabream [109]. $E_{2}$ modulate vertebrate granulocyte function through a GPER via PI3K in common carp macrophages [99] or through cAMP/protein kinase A/CREB signalling pathways in gilthead seabream granulocytes [109].

Table 2. Presence of different sex steroid receptors on leukocytes and immune tissues of different teleost species.

\begin{tabular}{ccccc}
\hline Sex Steroid & Receptor & Tissue or Cells & Fish Specie & References \\
\hline & & Spleen, blood and head-kidney cells & Channel catfish & {$[113]$} \\
& Macrophages & Gilthead seabream & {$[66]$} \\
& & Common carp & {$[99]$} \\
$E_{2}$ & ESR1 & Coutrophils & Gilthead seabream & {$[69]$} \\
& & Cymphocytes & Common carp & {$[99]$} \\
& Thymocytes & European sea bass & {$[98]$} \\
& Mast cells & Gilthead seabream & {$[98]$} \\
\end{tabular}


Table 2. Cont.

\begin{tabular}{|c|c|c|c|c|}
\hline Sex Steroid & Receptor & Tissue or Cells & Fish Specie & References \\
\hline & \multirow{7}{*}{ ESR2 } & Spleen & Channel catfish & [113] \\
\hline & & Spleen and head-kidney & Common sole & [97] \\
\hline & & Macrophages & Common carp & [99] \\
\hline & & Neutrophils & Common carp & [99] \\
\hline & & Lymphocytes & Common carp & [99] \\
\hline & & Thymocytes & European sea bass & [98] \\
\hline & & Mast cells & European sea bass & [98] \\
\hline & \multirow{3}{*}{ GPER } & Macrophages & Common carp & [99] \\
\hline & & Acidophilic granulocytes & Gilthead seabream & [109] \\
\hline & & Peritoneal leukocytes & Gilthead seabream & [89] \\
\hline \multirow{10}{*}{ Androgens } & \multirow{9}{*}{$\mathrm{AR}$} & \multirow{3}{*}{ Head-kidney } & salmonids & [114] \\
\hline & & & European sea bass & [115] \\
\hline & & & Zebrafish & [116] \\
\hline & & \multirow{2}{*}{ Liver } & European sea bass & [115] \\
\hline & & & Zebrafish & [116] \\
\hline & & \multirow{2}{*}{ Spleen } & European sea bass & [115] \\
\hline & & & Zebrafish & [116] \\
\hline & & Macrophages & Gilthead seabream & [91] \\
\hline & & Acidophilic granulocytes & Gilthead seabream & [91] \\
\hline & AR $\triangle \mathrm{LBD}$ variant & Acidophilic granulocytes & Gilthead seabream & [117] \\
\hline
\end{tabular}

\section{Influence of Androgens on Fish Immune Responses}

The effect of androgens on the immune system of fish has been less studied than the effect of oestrogens (Table 1). The androgen system of fish is quite complex, due to the fact that $\mathrm{T}$ is the main metabolite to be transformed into 11KT, OHT or DHT [14]. All of them have androgenic effects on fish reproductive tissues and have a role in the regulation of gametogenesis [118]. Moreover, DHT can also be transformed into $5 \alpha$-androstane- $3 \beta, 17 \beta$-diol ( $\beta$-diol), which has estrogenic activities [119]. In fish, these transformations occurred in several tissues including the testes, brain and liver [14,118]. The in vivo administration of $\mathrm{T}$ modifies the serum levels of other androgens and even those of $\mathrm{E}_{2}$. Thus, $\mathrm{T}$ administration increases $\mathrm{T}$ and $11 \mathrm{KT}$ and decreases DHT levels in serum of gilthead seabream [120]. As androgens are transformed in several tissues, the effect observed upon the exogenous administration of one of them could be due to the administered androgen or to the increase or decrease in the amount of any of the others into which the administered androgen could be transformed. For that, the importance of each androgen in the regulation of the immune response using in vivo experiments is not easy, as might be expected. In that sense, some in vitro data might help to clarify this issue. As in the case of oestrogens, many aquatic pollutants disrupt androgen signalling in fish [6].

\subsection{Testosterone}

The immunocompetence-handicap hypothesis is that $\mathrm{T}$ inhibits the immune response in order to guarantee the health of those specimens with well-developed testosterone-dependent sexual signals and that the activation of an immune response leads to a decrease of $T$ serum levels [121]. In salmonids, the immunosuppression observed in some stages of the reproductive cycle has been linked to androgens since leukocytes display a specific androgen receptor (AR) [114]. In fact, in vitro exposure of salmonid leukocytes to $\mathrm{T}$ decreases the ability of head kidney lymphocytes to form specific antibody producing cells [94] and triggered the death of total head kidney leukocytes [122]. In rainbow trout, $\mathrm{T}$ also causes a reduction in IgM secreting cells in peripheral blood, head kidney, spleen and skin leukocytes [79].

However, as data about the effect of $\mathrm{T}$ on different fish species and immune tissues are accumulated, the empirical evidence supporting the immunocompetence-handicap hypothesis in fish becomes weaker. In tench (Tinca tinca L.) the activation of an immune response upon $\beta$-glucan exposure decreased the serum levels of $\mathrm{T}$ that was predicted by the immunocompetence-handicap 
hypothesis [92]. However, $\mathrm{T}$ did not suppress the lysozyme activity of plasma or the production of ROIs by blood leukocytes and head kidney phagocytes [92] as also occurs with the phagocytic activity of peripheral blood of tilapia and common carp when treated in vitro with $\mathrm{T}$ [68]. In fact, in common carp, $\mathrm{T}$ has tissue-dependent effects on leukocytes as it sharply reduced the number of IgM secreting cells and IgM production in splenic leukocytes but not in circulating blood and head kidney leukocytes [81].

Surprisingly, the innate immune system of gilthead seabream is stimulated by T. Thus, in vivo an increase of serum $\mathrm{T}$ levels triggered high complement and peroxidase activity levels [78]. $\mathrm{T}$ also primed the phagocytosis and ROIs production activities of head kidney leukocytes in vitro [91] and in vivo [90]. In fact, the transcription levels of interleukin $1 \beta, i l 1 b$ and some tlrs genes are up-regulated in T-exposed head kidney leukocytes in vivo [90], as also occurred when professional phagocytic cells were isolated and treated with $\mathrm{T}$ in vitro [91].

\subsection{1-Ketotestosterone}

As $11 \mathrm{KT}$ is the main androgen in fish, most studies into androgen regulation of the immune response have used this androgen. In rainbow trout, $11 \mathrm{KT}$ triggers the same effect as $\mathrm{T}$, decreasing the number and capability of IgM-secreting cells of spleen, head kidney, blood and skin [79]. ROIs production and the phagocytic activity of common carp head kidney macrophages also decreased by $11 \mathrm{KT}$ [70]. However, when peripheral blood phagocytic activity after 11KT exposure was analysed, no effects were observed in common carp or tilapia [68], nor in the apoptotic rate of splenic or peripheral blood leukocytes of common carp [123]. In gilthead seabream, 11KT is able to increase proIL-1 $\beta$ accumulation and the ROIs production activity of non-stimulated head kidney phagocytes [67]. However, 11KT impairs the activation of the ROIs production by total head kidney leukocytes upon challenge with bacterial DNA in vitro [91]. Moreover, acidophilic granulocytes and macrophages of gilthead seabream did not respond equally to $11 \mathrm{KT}$. Thus, $11 \mathrm{KT}$ was quite effective at decreasing the gene expression of several tlrs in isolated acidophilic granulocytes activated or not with bacterial DNA, while in activated or non-activated macrophages the expression of $i l 1 b$ and tlrs increased in a dose-dependent manner at most of the doses used [91]. Interestingly, when macrophages are treated with $\mathrm{T}$ and $11 \mathrm{KT}$ simultaneously, $\mathrm{T}$ inhibits the up-regulation of $i l 1 b$ and $t l r 9$ genes induced by 11KT [91]. In male three-spined sticklebacks (Gasterosteus aculeatus), a negative correlation between $11 \mathrm{KT}$ serum levels and ROIs production in the phagocytosis assay was observed [94].

\subsection{Other C-19 Steroid with Androgenic Function}

In fish, DHT and OHT are also produced from $\mathrm{T}$ and in some species, they are the main androgens found in plasma or testis. Thus, in urohaze goby (Glossogobius olivaceus), the main androgen is DHT, which is produced by $\mathrm{T}$ conversion in several tissues including brain and gonad. Recent studies have demonstrated that DHT has androgenic functions in juvenile fathead minnows (Pimephales promelas) where it triggers testicular development through the first spermatogenetic wave and the appearance of intersex in females [124]. Moreover, in male gilthead seabream specimens, the increase in DHT triggers the meiotic phases of spermatogenesis, which seems to be regulated by $E_{2}$ and $T$ serum levels [120]. The OHT is also a potent androgen in some fish species, which is produced in gonad, liver and even blood cells $[125,126]$. There are not studies that relate DHT or OHT with the immune system. However, taking into account fresh data about the ability of these androgens to activate ARs [127], such studies would be performed and will probably shed more light on the complex and controversial data related with androgen effect on leukocytes.

\subsection{Androgen Receptors in Fish Leukocytes}

In salmonids the presence of ARs has been described in total head kidney leukocytes of rainbow trout [114]; however, little further information has been accumulated. Two nuclear ARs (ARa and ARb) have been described in cDNA libraries or in transcriptional studies performed in the testes of several 
fish species [128]. ARs expression has been reported in immune competent organs (Table 2), such as the head kidney, liver and spleen of sea bass [115] and zebrafish [116]. Recent studies performed in gilthead seabream described the presence of an AR in macrophages and acidophilic granulocytes [91]. It should be noted that all the in vitro data obtained in gilthead seabream macrophages and acidophilic granulocytes were determined only upon $3 \mathrm{~h}$ of stimulation with androgens, suggesting the existence of a membrane androgen receptor (mAR), as occurs in mammals [129]. However, in fish this membrane receptor has not been described to date. Mammalian AR is transcriptionally modified to form several variants of the ARs that have differential expressions and functions, mainly in cancer cell lines [129]. In gilthead seabream a splice-variant of the AR, the AR $\triangle$ LBD variant, occurs in acidophilic granulocytes but not in macrophages [117], while AR is expressed in both cell types [91]. T up-regulate the AR and ARALBD transcription in acidophilic granulocytes [91,117]; the AR $\triangle \mathrm{LBD} / \mathrm{AR}$ ratio is positively correlated with T serum levels [117]. Furthermore, the activation of acidophilic granulocytes with bacterial DNA modulates the $\mathrm{AR} \triangle \mathrm{LBD} / \mathrm{AR}$ ratio in a reproductive stage-dependent way [117], inducing a decrease during spermatogenesis stage and an increase during spawning. Although further studies are needed, the existence of several variants of ARs in fish leukocytes, together with the affinity of all the androgens previously described to ARs, may lead to an array of different sensitivities in the cells to different androgen levels.

\section{Influence of Progestins on Fish Immune Responses}

Natural progestins regulate several reproductive processes in vertebrates. A major progestin in fish teleost is $17 \alpha, 20 \beta$-dihydroxy-4-pregnen-3-one (DHP), which has been seen to be involved in sperm hydration and the activation of motility in some fish species $[15,16]$. Another related progestin is $17 \alpha, 20 \alpha$-dihydroxy-4-pregnen-3-one, the spermation-inducing hormone in amphibian species [130]. However, progestins also have an essential role in early gametogenesis, triggering the meiosis of male germ cells [17]. Synthetic progestins are used in humans as part of contraceptive therapies and it has also been claimed that they mainly impair $\mathrm{T}$ cell functions. These progestins inhibit the production of T-cell derived factors and alter the subset populations of $\mathrm{T}$ cells and their ratios. Moreover, the progestin, medroxyprogesterone (MPA), blocks $\mathrm{E}_{2}$ pro-inflammatory effects in several tissues such as injured vessels, endometrium and cervix [131,132]. In fish, however, to the best of our knowledge, two studies pointed to a role for progestins in the immune response of fish. In carp (Cyprinus carpio), DHP and MPA inhibit NO release by activated leukocytes as well as down-regulate the transcription of pro-inflammatory type I immune related-factors [133]. Interestingly, in tilapia (Oreochromis niloticus X O. aureus) progesterone had no suppressive effect on phagocytosis activity [68].

\section{Progestins Receptors in Fish Leukocytes}

Nuclear and membrane progestin receptors have been characterized in the reproductive tissues of several fish species. For example, 5 membrane receptors and 2 nuclear receptors have been described in European eel [108]. Interestingly, in reproductive tissues and brain, two different membrane proteins have been described [134]. The first one is the progesterone membrane receptor (mPR) that displays high affinity and specificity for progestin binding and promotes progestin signalling in vertebrate tissues, including fish. The second one is the progesterone receptor membrane component 1 (PGMRC1), which belongs to the membrane-associated progesterone receptor family and has been described in mammals [134]. This evidence points to a very complex network of receptors that leads to progestins biological activity in reproductive tissues. As fish leukocytes display a wide array of different hormone receptors $[135,136]$, the presence of progestin receptors seems to be feasible and further studies on progestin and its receptors on fish leukocytes need to be performed in order to have a better understanding of the effect of sex steroids on the immune system of fish. 


\section{Immune System in the Fish Gonad}

The gonad is the main steroidogenic organ in vertebrates and the levels of sex steroids in this organ may be even higher than those found in serum [137]. The gonad is considered an immune-privileged organ due to the ability of foreign tissue allografts to survive inside this organ, as the immune response is not activated against them. However, although physical barriers are present in the testis of all vertebrates, this is not the main mechanism underlying this phenomenon. This special status is mainly due to active local mechanisms of regulation that suppress the activation of leukocytes [138]. In fact, acidophilic granulocytes of gilthead seabream come into close contact with germ cells at certain stages of the reproductive cycle without triggering any inflammatory response and without phagocytizing them [139]. Moreover, leukocytes located in mammalian gonads orchestrate important reproductive physiology processes, including gametogenesis and steroidogenesis [140,141]. Much time has passed since leukocytes were first described in the gonad of teleosts. Since them, several types of leukocytes have been described in the testis of different teleost species using light and electron microscopy, while functional analysis has also been applied to gonadal leukocytes in several fish species. Thus, changes in the number and localization of leukocytes have been described in several fish species related to stages in the reproductive cycle [142]. The leukocytes described are macrophages, granulocytes, histamine positive cells and lymphocytes [67,143-145]. In fact, both IgM and IgT gene expression has been observed in fish testes [146], suggesting the presence of two different subsets of B lymphocytes. Interestingly, the acidophilic granulocytes are actively recruited by the gonad in physiological and non-pathological conditions through the regulation of adhesion molecule transcription and the production of chemiotactic factor [22,139]. In fact, when oestrogen or androgen serum levels are experimentally increased, the rate of leukocyte recruitment in the gonad is modified $[137,146]$. In rainbow trout a fish specific chemokine receptor, which has no equivalent in humans, is transcripted in the gonad [147]. Interestingly, the epigonal organ is a lymphomyeloid organ present in the elasmobranch gonad, whose haematopoietic activity seems to be correlated to hormone levels [148]. Moreover, the amount of leukocytes (macrophages, neutrophils and lymphocytes) presents in the ovarian cavity of Neoditrema ransonneti, a viviparous teleost species, are related with the reproductive cycle stages independently of the presence of semen in this cavity [149]. Functional data reveal that gonadal leukocytes of gilthead seabream have a specific pattern of activation completely different to the pattern shown by their head kidney counterparts. Thus, testicular acidophilic granulocytes have very low levels of ROIs production and a heavily suppressed phagocytic activity, while they constitutively express and accumulate IL1 $\beta[67,139]$. The metalloprotease profile displayed by testicular acidophilic granulocytes is also different from their head kidney counterparts [150]. All these data suggest that fish leukocytes might be very sensitive to sex steroid levels and are crucial to our understanding of this process so that their sensitivity to pollution by EDCs can be properly assessed.

The special regulation of the immune response in gonad is particularly relevant in the analysis of pathogens that may be transmitted to the following generation through the ovarian and seminal fluids or even inside the gametes (vertical transmission). Interestingly, several infectious pancreatic necrosis virus (IPNV)-detecting assays have reported differences when the samples were processed at different stages of the reproductive cycle [151], strongly suggesting an interaction between reproductive parameters and the virus life cycle and probably interference in the immune regulation of the gonad. Thus, several studies have determined and characterized the gonadal immune response upon virus colonization using different fish/virus models. IPNV and viral haemorrhagic septicaemia virus (VHSV) colonized the ovary of rainbow trout, although only VHSV actively produces enough mRNA and protein to be detected, while IPNV triggered a latent infection of the ovary [152]. In turn, VHSV strongly induces the activation of the transcription rates of several chemokines, interferon and myxovirus (influenza) resistance protein $(\mathrm{mx})$ genes, while IPNV neither elicits nor inhibits these responses [152]. Interestingly, the suppression of the immune response upon IPNV colonization of the ovary seems to be related to the exogenous systemic factors produced during IPNV infection [153]. A different immune response has been reported in the testis of European sea bass and gilthead 
seabream specimens upon NNV infection [154]. In general, the immune response was induced in European sea bass, while in gilthead seabream a viral mRNA and protein production was detected in testis [154]. The rapid immune response elicited in the gilthead seabream brain (target tissue of NNV) and not in the gonad, allows the specimens to survive the viral infection and to become carrier of the virus. Interestingly, the production of $E_{2}$ and $11 \mathrm{KT}$ was altered upon NNV infection [154], suggesting that the virus might alter the reproductive function in order to improve its own transmission or the immune response as sex steroids also regulated inflammation and other immune responses (see above). In fact, a positive correlation between the transcription levels of ESRb2 and several ARN sensor, intermediate and effector molecules of the interferon (IFN) pathway in the testis of European sea bass [155], the implications of which are being studied in our laboratory.

\section{The Effect of Other Hormones on the Immune Function}

Although this is not the main scope of this review, we mention many other biological processes in which a clear connection between hormones and immune functions exists. Moreover, leukocytes display multiple hormone receptors that modulate their activation and functions and, in turn, the immune response [135].

The response to stress involves a range of mechanisms that allow to readjust the homeostasis of an organism that has been altered upon the action of an intrinsic or extrinsic stressors [156]. The release of cortisol into blood stream is one of the main indicators of stress in fish [156]. Cortisol is involved in the regulation of the immune response but also regulates reproduction. The regulatory pathways of sex steroids and cortisol production are known to be interconnected [157]. Thus, cortisol induces immunosuppression but also regulates sex reversal by means of which environmental conditions can altered the fish sex determination and induce the development of another sexual phenotype [157]. In addition, it has recently been described that the sensitivity of leukocytes to sex steroids is regulated by cortisol and stress conditions through regulation of the transcription and production of ESRs, GPER1 and local aromatase [158].

Another interesting biological process related with reproduction is the smoltification of salmonids, by means of which, the specimens are able to migrate from freshwater to marine water, while adapting their biological processes to salinity [159]. This process is related with puberty and is orchestrated by hormones such as growth hormone, cortisol and thyroid hormones [135]. Interestingly, although increases in $11 \mathrm{KT}, \mathrm{T}$ and $\mathrm{E}_{2}$ serum levels have been observed during smoltification in salmonids, the exogenous administration of these hormones inhibited spring time smoltification in masu salmon [160]. Immunosuppression has been observed during smoltification, which is related with high levels of cortisol [159]; however, further studies are needed to expand our knowledge about this developmental process, which is critical for the improvement of salmonids aquaculture by preventing diseases and pathological losses.

\section{Conclusions}

In conclusion, the data accumulated to date reveal that fish leukocytes are sensitive to sex steroids. As most of the studies have been carried out with oestrogens or analyzed oestrogen regulation, to date is possible to conclude that they modulate the fish immune response. However, although some data about the influence of androgens and progestins on the fish immune response exists, more studies are needed to have a clear overview of this process. Taking into account that the immune response is essential for fish survival mainly during critical biological process such as stress responses, smoltification, sex change and reversal or even the blockage of viral transmission through the gonad, a better understanding of this regulation will improve fish production.

Acknowledgments: We thank the "Servicio de Apoyo a la Investigación" of the University of Murcia for their assistance with cell culture, flow cytometry and real-time PCR. This work was funded with support from the Spanish Ministerio de Economía y Competitividad (MINECO) (AGL2014-53167-C3-1-R and -2-R), the European Commission (FEDER/ERDF) and the Fundación Séneca, CARM (19883/GERM/15). 
Author Contributions: All authors worked on the manuscript and have read and approved the final manuscript.

Conflicts of Interest: The authors declare no conflict of interest.

\section{References}

1. Tokarz, J.; Möller, G.; Hrabě de Angelis, M.; Adamski, J. Steroids in teleost fishes: A functional point of view. Steroids 2015, 103, 123-144. [CrossRef] [PubMed]

2. Khan, D.; Ansar Ahmed, S. The immune system is a natural target for estrogen action: Opposing effects of estrogen in two prototypical autoimmune diseases. Front. Immunol. 2015, 6, 635. [CrossRef] [PubMed]

3. Scholz, S.; Mayer, I. Molecular biomarkers of endocrine disruption in small model fish. Mol. Cell. Endocrinol. 2008, 293, 57-70. [CrossRef] [PubMed]

4. Segner, H. Zebrafish (Danio rerio) as a model organism for investigating endocrine disruption. Comp. Biochem. Physiol. Part C Toxicol. Pharmacol. 2009, 149, 187-195. [CrossRef] [PubMed]

5. Hampl, R.; Kubátová, J.; Stárka, L. Steroids and endocrine disruptors-History, recent state of art and open questions. J. Steroid Biochem. Mol. Biol. 2016, 155, 217-223. [CrossRef] [PubMed]

6. Milla, S.; Depiereux, S.; Kestemont, P. The effects of estrogenic and androgenic endocrine disruptors on the immune system of fish: A review. Ecotoxicology 2011, 20, 305-319. [CrossRef] [PubMed]

7. Diotel, N.; Do Rego, J.L.; Anglade, I.; Vaillant, C.; Pellegrini, E.; Vaudry, H.; Kah, O. The brain of teleost fish, a source, and a target of sexual steroids. Front. Neurosci. 2011, 5, 137-153. [CrossRef] [PubMed]

8. Miller, W.L. Steroid hormone synthesis in mitochondria. Mol. Cell. Endocrinol. 2013, 379, 62-73. [CrossRef] [PubMed]

9. Arukwe, A. Steroidogenic acute regulatory (StAR) protein and cholesterol side-chain cleavage (P450scc)-regulated steroidogenesis as an organ-specific molecular and cellular target for endocrine disrupting chemicals in fish. Cell Biol. Toxicol. 2008, 24, 527-540. [CrossRef] [PubMed]

10. Hess, R.A. Estrogen in the adult male reproductive tract: A review. Reprod. Biol. Endocrinol. 2003, 1, 1-52. [CrossRef] [PubMed]

11. Chaves-Pozo, E.; Arjona, F.J.; García-López, A.; García-Alcázar, A.; Meseguer, J.; García-Ayala, A. Sex steroids and metabolic parameter levels in a seasonal breeding fish (Sparus aurata L.). Gen. Comp. Endocrinol. 2008, 156, 531-536. [CrossRef] [PubMed]

12. Valero, Y.; Sánchez-Hernández, M.; García-Alcázar, A.; García-Ayala, A.; Cuesta, A.; Chaves-Pozo, E. Characterization of the annual regulation of reproductive and immune parameters on the testis of European sea bass. Cell Tissue Res. 2015, 362, 215-229. [CrossRef] [PubMed]

13. Martyniuk, C.J.; Bissegger, S.; Langlois, V.S.V.S. Reprint of "Current perspectives on the androgen 5 alpha-dihydrotestosterone (DHT) and 5 alpha-reductases in teleost fishes and amphibians". Gen. Comp. Endocrinol. 2014, 203, 10-20. [CrossRef] [PubMed]

14. Borg, B. Androgens in teleost fishes. Comp. Biochem. Physiol. Part C Comp. 1994, 109, 219-245. [CrossRef]

15. Miura, T.; Yamauchi, K.; Takahashi, H.; Nagahama, Y. The role of hormones in the acquisition of sperm motility in salmonid fish. J. Exp. Zool. 1992, 261, 359-363. [CrossRef] [PubMed]

16. Ueda, H.; Kambegawa, A.; Nagahama, Y. Involvement of gonadotrophin and steroid hormones in spermiation in the amago salmon, Oncorhynchus rhodurus, and goldfish, Carassius auratus. Gen. Comp. Endocrinol. 1985, 59, 24-30. [CrossRef]

17. Miura, T.; Higuchi, M.; Ozaki, Y.; Ohta, T.; Miura, C. Progestin is an essential factor for the initiation of the meiosis in spermatogenetic cells of the eel. Proc. Natl. Acad. Sci. USA 2006, 103, 7333-7338. [CrossRef] [PubMed]

18. Hammond, G.L. Diverse roles for sex hormone-binding globulin in reproduction. Biol. Reprod. 2011, 85, 431-441. [CrossRef] [PubMed]

19. Bowden, T.J.; Thompson, K.D.; Morgan, A.L.; Gratacap, R.M.L.; Nikoskelainen, S. Seasonal variation and the immune response: A fish perspective. Fish Shellfish Immunol. 2007, 22, 695-706. [CrossRef] [PubMed]

20. Valero, Y.; García-Alcázar, A.; Esteban, M.A.; Cuesta, A.; Chaves-Pozo, E. Seasonal variations of the humoral immune parameters of European sea bass (Dicentrarchus labrax L.). Fish Shellfish Immunol. 2014, 39, 185-187. [CrossRef] [PubMed]

21. Esteban, M.A.; Cuesta, A.; Chaves-Pozo, E.; Meseguer, J. Influence of melatonin on the immune system of fish: A review. Int. J. Mol. Sci. 2013, 14, 7979-7999. [CrossRef] [PubMed] 
22. Chaves-Pozo, E.; Liarte, S.; Fernández-Alacid, L.; Abellán, E.; Meseguer, J.; Mulero, V.; García-Ayala, A. Pattern of expression of immune-relevant genes in the gonad of a teleost, the gilthead seabream (Sparus aurata L.). Mol. Immunol. 2008, 45, 2998-3011. [CrossRef] [PubMed]

23. Villeneuve, D.L.; Blake, L.S.; Brodin, J.D.; Greene, K.J.; Knoebl, I.; Miracle, A.L.; Martinovic, D.; Ankley, G.T. Transcription of key genes regulating gonadal steroidogenesis in control and ketoconazole- or vinclozolin-exposed fathead minnows. Toxicol. Sci. 2007, 98, 395-407. [CrossRef] [PubMed]

24. Szwejser, E.; Verburg-van Kemenade, B.M.L.; Maciuszek, M.; Chadzinska, M. Estrogen-dependent seasonal adaptations in the immune response of fish. Horm. Behav. 2017, 88, 15-24. [CrossRef] [PubMed]

25. Whitfield, G.K.; Jurutka, P.W.; Haussler, C.A.; Haussler, M.R. Steroid hormone receptors: Evolution, ligands, and molecular basis of biologic function. J. Cell. Biochem. 1999, 75, 110-122. [CrossRef]

26. Thomas, P.; Dressing, G.; Pang, Y.; Berg, H.; Tubbs, C.; Benninghoff, A.; Doughty, K. Progestin, estrogen and androgen G-protein coupled receptors in fish gonads. Steroids 2006, 71, 310-316. [CrossRef] [PubMed]

27. Whyte, S.K. The innate immune response of finfish-a review of current knowledge. Fish Shellfish Immunol. 2007, 23, 1127-1151. [CrossRef] [PubMed]

28. Rombout, J.; Huttenhuis, H.; Picchietti, S.; Scapigliati, G. Phylogeny and ontogeny of fish leucocytes. Fish Shellfish Immunol. 2005, 19, 441-455. [CrossRef] [PubMed]

29. Abruzzini, A.F.; Ingram, L.O.; Clem, L.W. Temperature-mediated processes in teleost immunity: Homeoviscous adaptation in teleost lymphocytes. Proc. Soc. Exp. Biol. Med. 1982, 169, 12-18. [CrossRef] [PubMed]

30. Avtalion, R.R.; Clem, L.W. Environmental control of the immune response in fish. Crit. Rev. Environ. Control 1981, 11, 163-188. [CrossRef]

31. Cuchens, M.A.; Clem, L.W. Phylogeny of lymphocyte heterogeneity. II. Differential effects of temperature on fish T-like and B-like cells. Cell. Immunol. 1977, 34, 219-230. [CrossRef]

32. Hoseinifar, S.H.; Esteban, M.A.; Cuesta, A.; Sun, Y.-Z. Prebiotics and fish immune response: A review of current knowledge and future perspectives. Rev. Fish. Sci. Aquac. 2015, 23, 315-328. [CrossRef]

33. Magnadóttir, B. Innate immunity of fish (overview). Fish Shellfish Immunol. 2006, 20, 137-151. [CrossRef] [PubMed]

34. Makrinos, D.L.; Bowden, T.J. Natural environmental impacts on teleost immune function. Fish Shellfish Immunol. 2016, 53, 50-57. [CrossRef] [PubMed]

35. Abbas, A.K.; Lichtman, A.H.; Pillai, S. Cellular and Molecular Immunology, 7th ed.; Elsevier: Amsterdam, The Netherlands, 2012.

36. Takeuchi, O.; Akira, S. Pattern recognition receptors and inflammation. Cell 2010, 140, 805-820. [CrossRef] [PubMed]

37. Crowhurst, M.O.; Layton, J.E.; Lieschke, G.J. Developmental biology of zebrafish myeloid cells. Int. J. Dev. Biol. 2002, 46, 483-492. [PubMed]

38. Dos Santos, N.M.; Romano, N.; de Sousa, M.; Ellis, A.E.; Rombout, J.H.W. Ontogeny of B and T cells in sea bass (Dicentrarchus labrax, L.). Fish Shellfish Immunol. 2000, 10, 583-596. [CrossRef] [PubMed]

39. Salinas, I.; Zhang, Y.-A.; Sunyer, J.O. Mucosal immunoglobulins and B cells of teleost fish. Dev. Comp. Immunol. 2011, 35, 1346-1365. [CrossRef] [PubMed]

40. Trede, N.S.; Zapata, A.; Zon, L.I. Fishing for lymphoid genes. Trends Immunol. 2001, 22, 302-307. [CrossRef]

41. Rubio-Godoy, M. Teleost fish immunology. Review. Rev. Mex. Cienc. Pecu. 2010, 1, 47-57.

42. Parra, D.; Takizawa, F.; Sunyer, J.O. Evolution of B cell immunity. Annu. Rev. Anim. Biosci. 2013, 1, 65-97. [CrossRef] [PubMed]

43. Flajnik, M.F. The last flag unfurled? A new immunoglobulin isotype in fish expressed in early development. Nat. Immunol. 2005, 6, 229-230. [CrossRef] [PubMed]

44. Coward, K.; Bromage, N.R.; Little, D.C. Inhibition of spawning and associated suppression of sex steroid levels during confinement in the substrate-spawning Tilapia zillii. J. Fish Biol. 1998, 52, 152-165. [CrossRef]

45. Ohta, Y.; Flajnik, M. IgD, like IgM, is a primordial immunoglobulin class perpetuated in most jawed vertebrates. Proc. Natl. Acad. Sci. USA 2006, 103, 10723-10728. [CrossRef] [PubMed]

46. Mashoof, S.; Criscitiello, M. Fish immunoglobulins. Biology 2016, 5, 45. [CrossRef] [PubMed]

47. Acton, R.T.; Weinheimer, P.F.; Hall, S.J.; Niedermeier, W.; Shelton, E.; Bennett, J.C. Tetrameric immune macroglobulins in three orders of bony fishes. Proc. Natl. Acad. Sci. USA 1971, 68, 107-111. [CrossRef] [PubMed] 
48. Wilson, M.; Bengtén, E.; Miller, N.W.; Clem, L.W.; Pasquier, L.D.; Warr, G.W. A novel chimeric Ig heavy chain from a teleost fish shares similarities to IgD (evolution). Immunology 1997, 94, 4593-4597.

49. Danilova, N.; Bussmann, J.; Jekosch, K.; Steiner, L.A. The immunoglobulin heavy-chain locus in zebrafish: Identification and expression of a previously unknown isotype, immunoglobulin Z. Nat. Immunol. 2005, 6, 295-302. [CrossRef] [PubMed]

50. Edholm, E.S.; Bengten, E.; Wilson, M. Insights into the function of IgD. Dev. Comp. Immunol. 2011, 35, 1309-1316. [CrossRef] [PubMed]

51. Zhang, Y.-A.A.; Salinas, I.; Li, J.; Parra, D.; Bjork, S.; Xu, Z.; LaPatra, S.E.; Bartholomew, J.; Sunyer, J.O. IgT, a primitive immunoglobulin class specialized in mucosal immunity. Nat. Immunol. 2010, 11, 827-835. [CrossRef] [PubMed]

52. Solem, S.T.; Stenvik, J. Antibody repertoire development in teleosts: A review with emphasis on salmonids and Gadus morhua L. Dev. Comp. Immunol. 2006, 30, 57-76. [CrossRef] [PubMed]

53. Maisey, K.; Imarai, M. Diversity of teleost leukocyte molecules: Role of alternative splicing. Fish Shellfish Immunol. 2011, 31, 663-672. [CrossRef] [PubMed]

54. Da'as, S.; Teh, E.M.; Dobson, J.T.; Nasrallah, G.K.; McBride, E.R.; Wang, H.; Neuberg, D.S.; Marshall, J.S.; Lin, T.J.; Berman, J.N. Zebrafish mast cells possess an FceRI-like receptor and participate in innate and adaptive immune responses. Dev. Comp. Immunol. 2011, 35, 125-134. [CrossRef] [PubMed]

55. Fischer, U.; Utke, K.; Somamoto, T.; Kollner, B.; Ototake, M.; Nakanishi, T. Cytotoxic activities of fish leucocytes. Fish Shellfish Immunol. 2006, 20, 209-226. [CrossRef] [PubMed]

56. Quiniou, S.M.A.; Boudinot, P. Processing of fish Ig heavy chain transcripts: Diverse splicing patterns and unusual nonsense mediated decay. Dev. Comp. Immunol. 2011, 35, 949-958. [CrossRef] [PubMed]

57. Mutoloki, S.; Jørgensen, J.B.; Evensen, $\varnothing$. The adaptive immune response in fish. In Fish Vaccination; John Wiley \& Sons, Ltd.: Chichester, UK, 2014; pp. 104-115, ISBN 9781118806913.

58. Secombes, C. Will advances in fish immunology change vaccination strategies? Fish Shellfish Immunol. 2008, 25, 409-416. [CrossRef] [PubMed]

59. Yamaguchi, T.; Takizawa, F.; Fischer, U.; Dijkstra, J. Along the axis between type 1 and type 2 immunity; principles conserved in evolution from fish to mammals. Biology 2015, 4, 814-859. [CrossRef] [PubMed]

60. Uribe, C.; Folch, H.; Enriquez, R.; Moran, G. Innate and adaptive immunity in teleost fish: A review. Vet. Med. 2011, 56, 486-503.

61. Nelson, E.R.; Habibi, H.R. Estrogen receptor function and regulation in fish and other vertebrates. Gen. Comp. Endocrinol. 2013, 192, 15-24. [CrossRef] [PubMed]

62. Iwanowicz, L.R.; Ottinger, C.A. Estrogens, estrogen receptors and their role as immunoregulators in fish. In Fish Defenses; Zaccone, G., Meseguer, J., García-Ayala, A., Kapoor, B.G., Eds.; Science Publisher: Enfield, UK, 2009; Volume 1, pp. 277-322, ISBN 978-1-57808-327-5.

63. Liarte, S.; Chaves-Pozo, E.; Abellán, E.; Meseguer, J.; Mulero, V.; Canario, A.V.; García-Ayala, A. Estrogen-responsive genes in macrophages of the bony fish gilthead seabream: A transcriptomic approach. Dev. Comp. Immunol. 2011, 35, 840-849. [CrossRef] [PubMed]

64. Cabas, I.; Liarte, S.; García-Alcázar, A.; Meseguer, J.; Mulero, V.; García-Ayala, A. 17alpha-Ethynylestradiol alters the immune response of the teleost gilthead seabream (Sparus aurata L.) both in vivo and in vitro. Dev. Comp. Immunol. 2012, 36, 547-556. [CrossRef] [PubMed]

65. Liarte, S.; Cabas, I.; Chaves-Pozo, E.; Arizcun, M.; Meseguer, J.; Mulero, V.; García-Ayala, A. Natural and synthetic estrogens modulate the inflammatory response in the gilthead seabream (Sparus aurata L.) through the activation of endothelial cells. Mol. Immunol. 2011, 48, 1917-1925. [CrossRef] [PubMed]

66. Liarte, S.; Chaves-Pozo, E.; Abellán, E.; Meseguer, J.; Mulero, V.; García-Ayala, A. 17beta-Estradiol regulates gilthead seabream professional phagocyte responses through macrophage activation. Dev. Comp. Immunol. 2011, 35, 19-27. [CrossRef] [PubMed]

67. Chaves-Pozo, E.; Pelegrín, P.; Mulero, V.; Meseguer, J.; García-Ayala, A. A role for acidophilic granulocytes in the testis of the gilthead seabream (Sparus aurata L., Teleostei). J. Endocrinol. 2003, 179, 165-174. [CrossRef] [PubMed]

68. Law, W.Y.; Chen, W.H.; Song, Y.L.; Dufour, S.; Chang, C.F. Differential in vitro suppressive effects of steroids on leukocyte phagocytosis in two teleosts, tilapia and common carp. Gen. Comp. Endocrinol. 2001, 121, 163-172. [CrossRef] [PubMed] 
69. Wang, R.; Belosevic, M. The in vitro effects of estradiol and cortisol on the function of a long-term goldfish macrophage cell line. Dev. Comp. Immunol. 1995, 19, 327-336. [CrossRef]

70. Watanuki, H.; Yamaguchi, T.; Sakai, M. Suppression in function of phagocytic cells in common carp Cyprinus carpio L. injected with estradiol, progesterone or 11-ketotestosterone. Comp. Biochem. Physiol. C Toxicol. Pharmacol. 2002, 132, 407-413. [CrossRef]

71. Yamaguchi, T.; Watanuki, H.; Sakai, M. Effects of estradiol, progesterone and testosterone on the function of carp, Cyprinus carpio, phagocytes in vitro. Comp. Biochem. Physiol. C Toxicol. Pharmacol. 2001, 129, 49-55. [CrossRef]

72. Chaves-Pozo, E.; Liarte, S.; Vargas-Chacoff, L.; García-López, A.; Mulero, V.; Meseguer, J.; Mancera, J.M.; García-Ayala, A. 17Beta-estradiol triggers postspawning in spermatogenically active gilthead seabream (Sparus aurata L.) males. Biol. Reprod. 2007, 76, 142-148. [CrossRef] [PubMed]

73. Yi, H.Y.; Dong, H.X. Effects of estradiol-17beta on immunocompetence in rainbow trout (Oncorhynchus mykiss). Acta Zool. Sin. 2001, 47, 285-291.

74. Thilagam, H.; Gopalakrishnan, S.; Qu, H.D.; Bo, J.; Wang, K.J. 17beta estradiol induced ROS generation, DNA damage and enzymatic responses in the hepatic tissue of Japanese sea bass. Ecotoxicology 2010, 19, 1258-1267. [CrossRef] [PubMed]

75. Thilagam, H.; Gopalakrishnan, S.; Bo, J.; Wang, K.-J.J. Effect of 17beta-estradiol on the immunocompetence of Japanese sea bass (Lateolabrax japonicus). Environ. Toxicol. Chem. 2009, 28, 1722-1731. [CrossRef] [PubMed]

76. Seemann, F.; Knigge, T.; Rocher, B.; Minier, C.; Monsinjon, T. 17 $\beta$-Estradiol induces changes in cytokine levels in head kidney and blood of juvenile sea bass (Dicentrarchus labrax L., 1758). Mar. Environ. Res. 2013, 87-88, 44-51. [CrossRef] [PubMed]

77. Wenger, M.; Sattler, U.; Goldschmidt-Clermont, E.; Segner, H. 17Beta-estradiol affects the response of complement components and survival of rainbow trout (Oncorhynchus mykiss) challenged by bacterial infection. Fish Shellfish Immunol. 2011, 31, 90-97. [CrossRef] [PubMed]

78. Cuesta, A.; Vargas-Chacoff, L.; García-López, A.; Arjona, F.J.; Martínez-Rodríguez, G.; Meseguer, J.; Mancera, J.M.; Esteban, M.A. Effect of sex-steroid hormones, testosterone and estradiol, on humoral immune parameters of gilthead seabream. Fish Shellfish Immunol. 2007, 23, 693-700. [CrossRef] [PubMed]

79. Hou, Y.Y.; Suzuki, Y.; Aida, K. Effects of steroid hormones on immunoglobulin M (IgM) in rainbow trout, Oncorhynchus mykiss. Fish Physiol. Biochem. 1999, 20, 155-162. [CrossRef]

80. Hou, Y.; Suzuki, Y.; Aida, K. Effects of steroids on the antibody producing lymphocytes in rainbow trout. Fish. Sci. 1999, 65, 850-855. [CrossRef]

81. Saha, N.R.; Usami, T.; Suzuki, Y. In vitro effects of steroid hormones on IgM-secreting cells and IgM secretion in common carp (Cyprinus carpio). Fish Shellfish Immunol. 2004, 17, 149-158. [CrossRef] [PubMed]

82. Iwanowicz, L.R.; Stafford, J.L.; Patiño, R.; Bengten, E.; Miller, N.W.; Blazer, V.S. Channel catfish (Ictalurus punctatus) leukocytes express estrogen receptor isoforms ER $\alpha$ and ER $\beta 2$ and are functionally modulated by estrogens. Fish Shellfish Immunol. 2014, 40, 109-119. [CrossRef] [PubMed]

83. Wang, R.; Belosevic, M. Estradiol increases susceptibility of goldfish to Trypanosoma danilewskyi. Dev. Comp. Immunol. 1994, 18, 377-387. [CrossRef]

84. Hintemann, T.; Schneider, C.; Schöler, H.F.; Schneider, R.J. Field study using two immunoassays for the determination of estradiol and ethinylestradiol in the aquatic environment. Water Res. 2006, 40, 2287-2294. [CrossRef] [PubMed]

85. Johnson, A.C.; Aerni, H.R.; Gerritsen, A.; Gibert, M.; Giger, W.; Hylland, K.; Jurgens, M.; Nakari, T.; Pickering, A.; Suter, M.J.; et al. Comparing steroid estrogen, and nonylphenol content across a range of European sewage plants with different treatment and management practices. Water Res. 2005, 39, 47-58. [CrossRef] [PubMed]

86. Soffker, M.; Tyler, C.R.; Söffker, M.; Tyler, C.R. Endocrine disrupting chemicals and sexual behaviors in fish-A critical review on effects and possible consequences. Crit. Rev. Toxicol. 2012, 42, 653-668. [CrossRef] [PubMed]

87. Rodenas, M.C.; Cabas, I.; Abellán, E.; Meseguer, J.; Mulero, V.; García-Ayala, A. Tamoxifen persistently disrupts the humoral adaptive immune response of gilthead seabream (Sparus aurata L.). Dev. Comp. Immunol. 2015, 53, 283-292. [CrossRef] [PubMed] 
88. Rodenas, M.C.; Cabas, I.; García-Alcázar, A.; Meseguer, J.; Mulero, V.; García-Ayala, A. Selective estrogen receptor modulators differentially alter the immune response of gilthead seabream juveniles. Fish Shellfish Immunol. 2016, 52, 189-197. [CrossRef] [PubMed]

89. Gómez González, N.E.; Cabas, I.; Rodenas, M.C.; Arizcun, M.; Mulero, V.; García Ayala, A. $17 \alpha$-Ethynylestradiol alters the peritoneal immune response of gilthead seabream. Dev. Comp. Immunol. 2017, 76, 143-149. [CrossRef] [PubMed]

90. Castillo-Briceño, P.; Águila-Martínez, S.; Liarte, S.; García-Alcázar, A.; Meseguer, J.; Mulero, V.; García-Ayala, A. In situ forming microparticle implants for delivery of sex steroids in fish: Modulation of the immune response of gilthead seabream by testosterone. Steroids 2013, 78, 26-33. [CrossRef] [PubMed]

91. Águila, S.; Castillo-Briceño, P.; Sánchez, M.; Cabas, I.; García-Alcázar, A.; Meseguer, J.; Mulero, V.; García-Ayala, A. Specific and non-overlapping functions of testosterone and 11-ketotestosterone in the regulation of professional phagocyte responses in the teleost fish gilthead seabream. Mol. Immunol. 2013, 53, 218-226. [CrossRef] [PubMed]

92. Vainikka, A.; Jokinen, E.I.; Kortet, R.; Paukku, S.; Pirhonen, J.; Ratala, M.J.; Taskinen, J. Effects of testosterone and b-glucan on immune function in tench. J. Fish Biol. 2005, 66, 348-361. [CrossRef]

93. Slater, C.H.; Schreck, C.B. Testosterone alters the immune response of chinook salmon, Oncorhynchus tshawytscha. Gen. Comp. Endocrinol. 1993, 89, 291-298. [CrossRef] [PubMed]

94. Kurtz, J.; Kalbe, M.; Langefors, A.; Mayer, I.; Milinski, M.; Hasselquist, D. An experimental test of the immunocompetence handicap hypothesis in a teleost fish: 11-ketotestosterone suppresses innate immunity in three-spined sticklebacks. Am. Nat. 2007, 170, 509-519. [CrossRef] [PubMed]

95. Nagler, J.J.; Cavileer, T.; Sullivan, J.; Cyr, D.G.; Rexroad, C., 3rd. The complete nuclear estrogen receptor family in the rainbow trout: Discovery of the novel ERalpha2 and both ERbeta isoforms. Gene 2007, 392, 164-173. [CrossRef] [PubMed]

96. Xia, Z.; Gale, W.L.; Chang, X.; Langenau, D.; Patino, R.; Maule, A.G.; Densmore, L.D. Phylogenetic sequence analysis, recombinant expression, and tissue distribution of a channel catfish estrogen receptor beta. Gen. Comp. Endocrinol. 2000, 118, 139-149. [CrossRef] [PubMed]

97. Caviola, E.; Dalla Valle, L.; Belvedere, P.; Colombo, L. Characterisation of three variants of estrogen receptor beta mRNA in the common sole, Solea solea L. (Teleostei). Gen. Comp. Endocrinol. 2007, 153, 31-39. [CrossRef] [PubMed]

98. Paiola, M.; Knigge, T.; Picchietti, S.; Duflot, A.; Guerra, L.; Pinto, P.I.S.; Scapigliati, G.; Monsinjon, T. Oestrogen receptor distribution related to functional thymus anatomy of the European sea bass, Dicentrarchus labrax. Dev. Comp. Immunol. 2017, 77, 106-120. [CrossRef] [PubMed]

99. Szwejser, E.; Maciuszek, M.; Casanova-Nakayama, A.; Segner, H.; Verburg-van Kemenade, B.M.L. A role for multiple estrogen receptors in immune regulation of common carp. Dev. Comp. Immunol. 2017, 66, 61-72. [CrossRef] [PubMed]

100. López-Muñoz, A.; Liarte, S.; Gómez-González, N.E.; Cabas, I.; Meseguer, J.; García-Ayala, A.; Mulero, V. Estrogen receptor $2 \mathrm{~b}$ deficiency impairs the antiviral response of zebrafish. Dev. Comp. Immunol. 2015, 53, 55-62. [CrossRef] [PubMed]

101. Szego, C.M.; Davis, J.S. Adenosine 3',5'-monophosphate in rat uterus: Acute elevation by estrogen. Proc. Natl. Acad. Sci. USA 1967, 58, 1711-1718. [CrossRef] [PubMed]

102. Gu, Q.; Korach, K.S.; Moss, R.L. Rapid action of $17 \beta$-estradiol on kainate-induced currents in hippocampal neurons lacking intracellular estrogen receptors. Endocrinology 1999, 140, 660-666. [CrossRef] [PubMed]

103. Nadal, A.; Ropero, A.B.; Laribi, O.; Maillet, M.; Fuentes, E.; Soria, B. Nongenomic actions of estrogens and xenoestrogens by binding at a plasma membrane receptor unrelated to estrogen receptor alpha and estrogen receptor beta. Proc. Natl. Acad. Sci. USA 2000, 97, 11603-11608. [CrossRef] [PubMed]

104. Qiu, J.; Bosch, M.A.; Tobias, S.C.; Grandy, D.K.; Scanlan, T.S.; Ronnekleiv, O.K.; Kelly, M.J. Rapid signaling of estrogen in hypothalamic neurons involves a novel G-protein-coupled estrogen receptor that activates protein kinase C. J. Neurosci. 2003, 23, 9529-9540. [PubMed]

105. Revankar, C.M.; Cimino, D.F.; Sklar, L.A.; Arterburn, J.B.; Prossnitz, E.R. A transmembrane intracellular estrogen receptor mediates rapid cell signaling. Science 2005, 307, 1625-1630. [CrossRef] [PubMed]

106. Thomas, P.; Pang, Y.; Filardo, E.J.; Dong, J. Identity of an estrogen membrane receptor coupled to a G protein in human breast cancer cells. Endocrinology 2005, 146, 624-632. [CrossRef] [PubMed] 
107. Prossnitz, E.R.; Arterburn, J.B.; Sklar, L.A. GPR30: AG protein-coupled receptor for estrogen. Mol. Cell. Endocrinol. 2007, 265-266, 138-142. [CrossRef] [PubMed]

108. Morini, M.; Peñaranda, D.S.; Vílchez, M.C.; Tveiten, H.; Lafont, A.-G.; Dufour, S.; Pérez, L.; Asturiano, J.F. The expression of nuclear and membrane estrogen receptors in the European eel throughout spermatogenesis. Comp. Biochem. Physiol. Part A Mol. Integr. Physiol. 2017, 203, 91-99. [CrossRef] [PubMed]

109. Cabas, I.; Rodenas, M.C.; Abellán, E.; Meseguer, J.; Mulero, V.; García-Ayala, A. Estrogen signaling through the $\mathrm{G}$ protein-coupled estrogen receptor regulates granulocyte activation in fish. J. Immunol. 2013, 191, 4628-4639. [CrossRef] [PubMed]

110. Diamante, G.; Menjivar-Cervantes, N.; Leung, M.S.; Volz, D.C.; Schlenk, D. Contribution of G protein-coupled estrogen receptor 1 (GPER) to $17 \beta$-estradiol-induced developmental toxicity in zebrafish. Aquat. Toxicol. 2017, 186, 180-187. [CrossRef] [PubMed]

111. Mangiamele, L.A.; Gómez, J.R.; Curtis, N.J.; Thompson, R.R. GPER/GPR30, a membrane estrogen receptor, is expressed in the brain and retina of a social fish (Carassius auratus) and colocalizes with isotocin. J. Comp. Neurol. 2017, 525, 252-270. [CrossRef] [PubMed]

112. Thomas, P.; Alyea, R.; Pang, Y.; Peyton, C.; Dong, J.; Berg, A.H. Conserved estrogen binding and signaling functions of the $G$ protein-coupled estrogen receptor 1 (GPER) in mammals and fish. Steroids 2010, 75, 595-602. [CrossRef] [PubMed]

113. Patiño, R.; Xia, Z.; Gale, W.L.; Wu, C.; Maule, A.G.; Chang, X. Novel transcripts of the estrogen receptor alpha gene in channel catfish. Gen. Comp. Endocrinol. 2000, 120, 314-325. [CrossRef] [PubMed]

114. Slater, C.H.; Fitzpatrick, M.S.; Schreck, C.B. Characterization of an androgen receptor in salmonid lymphocytes: Possible link to androgen-induced immunosuppression. Gen. Comp. Endocrinol. 1995, 100, 218-225. [CrossRef] [PubMed]

115. Blazquez, M.; Piferrer, F. Sea bass (Dicentrarchus labrax) androgen receptor: CDNA cloning, tissue-specific expression, and mRNA levels during early development and sex differentiation. Mol. Cell. Endocrinol. 2005, 237, 37-48. [CrossRef] [PubMed]

116. De Waal, P.P.; Wang, D.S.; Nijenhuis, W.A.; Schulz, R.W.; Bogerd, J. Functional characterization and expression analysis of the androgen receptor in zebrafish (Danio rerio) testis. Reproduction 2008, 136, 225-234. [CrossRef] [PubMed]

117. Sánchez-Hernández, M.; Arizcun, M.; García-Alcázar, A.; Sarropoulou, E.; Mulero, V.; García-Ayala, A. Fish granulocytes express a constitutively active androgen receptor variant. Dev. Comp. Immunol. 2014, 45, 115-122. [CrossRef] [PubMed]

118. Taranger, G.L.; Carrillo, M.; Schulz, R.W.; Fontaine, P.; Zanuy, S.; Felip, A.; Weltzien, F.A.; Dufour, S.; Karlsen, O.; Norberg, B.; et al. Control of puberty in farmed fish. Gen. Comp. Endocrinol. 2010, 165, 483-515. [CrossRef] [PubMed]

119. Mouriec, K.; Gueguen, M.M.; Manuel, C.; Percevault, F.; Thieulant, M.L.; Pakdel, F.; Kah, O. Androgens upregulate cyp19a1b (aromatase B) gene expression in the brain of zebrafish (Danio rerio) through estrogen receptors. Biol. Reprod. 2009, 80, 889-896. [CrossRef] [PubMed]

120. García-García, M.; Sánchez-Hernández, M.; García-Hernández, M.P.; García-Ayala, A.; Chaves-Pozo, E. Role of $5 \alpha$-dihydrotestosterone in testicular development of gilthead seabream following finasteride administration. J. Steroid Biochem. Mol. Biol. 2017, 174, 48-55. [CrossRef] [PubMed]

121. Folstad, I.; Karter, A.J. Parasites, bright males, and the immunocompetence handicap. Am. Nat. 1992, 139, 603-622. [CrossRef]

122. Slater, C.H.; Schreck, C.B. Physiological levels of testosterone kill salmonid leukocytes in vitro. Gen. Comp. Endocrinol. 1997, 106, 113-119. [CrossRef] [PubMed]

123. Saha, N.R.; Usami, T.; Suzuki, Y. A double staining flow cytometric assay for the detection of steroid induced apoptotic leucocytes in common carp (Cyprinus carpio). Dev. Comp. Immunol. 2003, 27, 351-363. [CrossRef]

124. Margiotta-Casaluci, L.; Sumpter, J.P. 5alpha-Dihydrotestosterone is a potent androgen in the fathead minnow (Pimephales promelas). Gen. Comp. Endocrinol. 2011, 171, 309-318. [CrossRef] [PubMed]

125. Rajakumar, A.; Senthilkumaran, B. Dynamic expression of $11 \beta$-hydroxylase during testicular development, recrudescence and after hCG induction, in vivo and in vitro in catfish, Clarias batrachus. Gen. Comp. Endocrinol. 2015, 211, 69-80. [CrossRef] [PubMed]

126. Schulz, R. In vitro metabolism of steroid hormones in the liver and in blood cells of male rainbow trout (Salmo gairdneri Richardson). Gen. Comp. Endocrinol. 1986, 64, 312-319. [CrossRef] 
127. Sperry, T.S.; Thomas, P. Characterization of two nuclear androgen receptors in Atlantic croaker: Comparison of their biochemical properties and binding specificities. Endocrinology 1999, 140, 1602-1611. [CrossRef] [PubMed]

128. Ikeuchi, T.; Todo, T.; Kobayashi, T.; Nagahama, Y. Two subtypes of androgen and progestogen receptors in fish testes. Comp. Biochem. Physiol. B Biochem. Mol. Biol. 2001, 129, 449-455. [CrossRef]

129. Louie, M.C.; Sevigny, M.B. Steroid hormone receptors as prognostic markers in breast cancer. Am. J. Cancer Res. 2017, 7, 1617-1636. [PubMed]

130. Kobayashi, T.; Sakai, N.; Adachi, S.; Asahina, K.; Iwasawa, H.; Nagahama, Y. 17alpha,20alpha-Dihydroxy-4pregnen-3-one is the naturally occurring spermiation-inducing hormone in the testis of a frog, Rana nigromaculata. Endocrinology 1993, 133, 321-327. [CrossRef] [PubMed]

131. Goldfien, G.A.; Barragan, F.; Chen, J.; Takeda, M.; Irwin, J.C.; Perry, J.; Greenblatt, R.M.; Smith-McCune, K.K.; Giudice, L.C. Progestin-containing contraceptives alter expression of host defense-related genes of the endometrium and cervix. Reprod. Sci. 2015, 22, 814-828. [CrossRef] [PubMed]

132. Huijbregts, R.P.H.; Michel, K.G.; Hel, Z. Effect of progestins on immunity: Medroxyprogesterone but not norethisterone or levonorgestrel suppresses the function of T cells and pDCs. Contraception 2014, 90, 123-129. [CrossRef] [PubMed]

133. Pietsch, C.; Neumann, N.; Knopf, K.; Wuertz, S.; Kloas, W. Progestogens cause immunosuppression of stimulated carp (Cyprinus carpio L.) leukocytes in vitro. Comp. Biochem. Physiol. C. Toxicol. Pharmacol. 2009, 150, 16-24. [CrossRef] [PubMed]

134. Thomas, P. Characteristics of membrane progestin receptor alpha (mPRalpha) and progesterone membrane receptor component 1 (PGMRC1) and their roles in mediating rapid progestin actions. Front. Neuroendocrinol. 2008, 29, 292-312. [CrossRef] [PubMed]

135. Verburg-van Kemenade, B.M.; Van der Aa, L.M.; Chadzinska, M. Neuroendocrine-immune interaction: Regulation of inflammation via G-protein coupled receptors. Gen. Comp. Endocrinol. 2013, 188, 94-101. [CrossRef] [PubMed]

136. Verburg-van Kemenade, B.M.L.; Ribeiro, C.M.S.; Chadzinska, M. Neuroendocrine-immune interaction in fish: Differential regulation of phagocyte activity by neuroendocrine factors. Gen. Comp. Endocrinol. 2011, 172, 31-38. [CrossRef] [PubMed]

137. Sánchez-Hernández, M.; Chaves-Pozo, E.; Cabas, I.; Mulero, V.; García-Ayala, A.; García-Alcázar, A. Testosterone implants modify the steroid hormone balance and the gonadal physiology of gilthead seabream (Sparus aurata L.) males. J. Steroid Biochem. Mol. Biol. 2013, 138, 183-194. [CrossRef] [PubMed]

138. Hedger, M.P. Immune privilege of the testis: Meaning, mechanisms, and manifestations. In Infection, Immune Homeostasis and Immune Privilege; Stein-Streilein, J., Ed.; Springer: Basel, Switzerland, 2012.

139. Chaves-Pozo, E.; Mulero, V.; Meseguer, J.; García-Ayala, A. Professional phagocytic granulocytes of the bony fish gilthead seabream display functional adaptation to testicular microenvironment. J. Leukoc. Biol. 2005, 78, 345-351. [CrossRef] [PubMed]

140. Hedger, M.P. Testicular leukocytes: What are they doing? Rev. Reprod. 1997, 2, 38-47. [CrossRef] [PubMed]

141. Dunbar, B.S.; Prasad, S.; Carino, C.; Skinner, S.M. The ovary as an immune target. J. Soc. Gynecol. Investig. 2001, 8, S43-S48. [PubMed]

142. Chaves-Pozo, E.; Liarte, S.; García-Ayala, A. Immune and reproductive interaction: An essential clue for understanding gonad functions in gilthead seabream. In Recent Advances in Fish Reproductive Biology; García-Ayala, A., Meseguer, J., Chaves-Pozo, E., Eds.; Research Signpost: Kerala, India, 2010; ISBN 978-81-308-0397-5.

143. Loir, M.; Sourdaine, P.; Mendis-Handagama, S.M.; Jegou, B. Cell-cell interactions in the testis of teleosts and elasmobranchs. Microsc. Res. Tech. 1995, 32, 533-552. [CrossRef] [PubMed]

144. Liarte, S.; Chaves-Pozo, E.; García-Alcázar, A.; Mulero, V.; Meseguer, J.; García-Ayala, A. Testicular involution prior to sex change in gilthead seabream is characterized by a decrease in DMRT1 gene expression and by massive leukocyte infiltration. Reprod. Biol. Endocrinol. 2007, 5, 20. [CrossRef] [PubMed]

145. García-García, M.; Liarte, S.; Gómez-González, N.E.; García-Alcázar, A.; Pérez-Sánchez, J.; Meseguer, J.; Mulero, V.; García-Ayala, A.; Chaves-Pozo, E. Cimetidine disrupts the renewal of testicular cells and the steroidogenesis in a hermaphrodite fish. Comp. Biochem. Physiol. C Toxicol. Pharmacol. 2016, 189, 44-53. [CrossRef] [PubMed] 
146. Cabas, I.; Chaves-Pozo, E.; García-Alcázar, A.; Meseguer, J.; Mulero, V.; García-Ayala, A. Dietary intake of 17alpha-ethinylestradiol promotes leukocytes infiltration in the gonad of the hermaphrodite gilthead seabream. Mol. Immunol. 2011, 48, 2079-2086. [CrossRef] [PubMed]

147. Dixon, B.; Luque, A.; Abós, B.; Castro, R.; González-Torres, L.; Tafalla, C. Molecular characterization of three novel chemokine receptors in rainbow trout (Oncorhynchus mykiss). Fish Shellfish Immunol. 2013, 34, 641-651. [CrossRef] [PubMed]

148. Lutton, B.V.; Callard, I.P. Morphological relationships and leukocyte influence on steroid production in the epigonal organ-ovary complex of the skate, Leucoraja erinacea. J. Morphol. 2008, 269, 620-629. [CrossRef] [PubMed]

149. Tazumi, Y.; Nakamura, O.; Watanabe, T. Intraovarian cavity leucocytes of viviparous fish, Neoditrema ransonneti (Perciformes, Embiotocidae). Zool. Sci. 2004, 21, 739-746. [CrossRef] [PubMed]

150. Chaves-Pozo, E.; Castillo-Briceño, P.; García-Alcázar, A.; Meseguer, J.; Mulero, V.; García-Ayala, A. A role for matrix metalloproteinases in granulocyte infiltration and testicular remodelation in a seasonal breeding teleost. Mol. Immunol. 2008, 45, 2820-2830. [CrossRef] [PubMed]

151. Munro, E.S.; Ellis, A.E. A comparison between non-destructive and destructive testing of Atlantic salmon, Salmo salar L., broodfish for IPNV_-Destructive testing is still the best at time of maturation. J. Fish Dis. 2008, 31, 187-195. [CrossRef] [PubMed]

152. Chaves-Pozo, E.; Montero, J.; Cuesta, A.; Tafalla, C. Viral hemorrhagic septicemia and infectious pancreatic necrosis viruses replicate differently in rainbow trout gonad and induce different chemokine transcription profiles. Dev. Comp. Immunol. 2010, 34, 648-658. [CrossRef] [PubMed]

153. Chaves-Pozo, E.; Zou, J.; Secombes, C.J.; Cuesta, A.; Tafalla, C. The rainbow trout (Oncorhynchus mykiss) interferon response in the ovary. Mol. Immunol. 2010, 47, 1757-1764. [CrossRef] [PubMed]

154. Valero, Y.; Arizcun, M.; Esteban, M.A.; Bandín, I.; Olveira, J.G.; Patel, S.; Cuesta, A.; Chaves-Pozo, E. Nodavirus colonizes and replicates in the testis of gilthead seabream and European sea bass modulating its immune and reproductive functions. PLoS ONE 2015, 10, e0145131. [CrossRef] [PubMed]

155. Valero, Y.; Morcillo, P.; Meseguer, J.; Buonocore, F.; Esteban, M.A.; Chaves-Pozo, E.; Cuesta, A. Characterization of the interferon pathway in the teleost fish gonad against the vertically transmitted viral nervous necrosis virus. J. Gen. Virol. 2015, 96, 2176-2187. [CrossRef] [PubMed]

156. Wendelaar Bonga, S.E. The stress response in fish. Physiol. Rev. 1997, 77, 591-625. [CrossRef] [PubMed]

157. Goikoetxea, A.; Todd, E.V.; Gemmell, N.J. Stress and sex: Does cortisol mediate sex change in fish? Reproduction 2017, 154, R149-R160. [CrossRef] [PubMed]

158. Szwejser, E.; Pijanowski, L.; Maciuszek, M.; Ptak, A.; Wartalski, K.; Duda, M.; Segner, H.; Verburg-van Kemenade, B.M.L.; Chadzinska, M. Stress differentially affects the systemic and leukocyte estrogen network in common carp. Fish Shellfish Immunol. 2017, 68, 190-201. [CrossRef] [PubMed]

159. Björnsson, B.T.; Stefansson, S.O.; Mccormick, S.D. Environmental endocrinology of salmon smoltification. Gen. Comp. Endocrinol. 2011, 170, 290-298. [CrossRef] [PubMed]

160. Yamada, H.; Ohta, H.; Yamauchi, K. Serum thyroxine, estradiol-17 $\beta$, and testosterone profiles during the parr-smolt transformation of masu salmon, Oncorhynchus masou. Fish Physiol. Biochem. 1993, 12, 1-9. [CrossRef] [PubMed]

(C) 2018 by the authors. Licensee MDPI, Basel, Switzerland. This article is an open access article distributed under the terms and conditions of the Creative Commons Attribution (CC BY) license (http://creativecommons.org/licenses/by/4.0/). 